\title{
Belgeo
}

Revue belge de géographie

1-2 | 2012

Inaugural issue

\section{There's no hope : The global economic crisis and the politics of resistance in Southern Europe}

La crise économique globale et les stratégies de résistance dans le sud de

l'Europe: un problème sans issue

\section{Ugo Rossi}

\section{OpenEdition}

\section{Journals}

Electronic version

URL: http://journals.openedition.org/belgeo/7071

DOI: 10.4000/belgeo.7071

ISSN: 2294-9135

Publisher:

National Committee of Geography of Belgium, Société Royale Belge de Géographie

\section{Electronic reference}

Ugo Rossi, «There's no hope: The global economic crisis and the politics of resistance in Southern Europe », Belgeo [Online], 1-2 | 2012, Online since 04 December 2012, connection on 01 May 2019. URL : http://journals.openedition.org/belgeo/7071 ; DOI : 10.4000/belgeo.7071

This text was automatically generated on 1 May 2019.

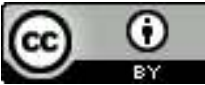

Belgeo est mis à disposition selon les termes de la licence Creative Commons Attribution 4.0 International. 


\title{
There's no hope: The global economic crisis and the politics of resistance in Southern Europe ${ }^{1}$
}

La crise économique globale et les stratégies de résistance dans le sud de l'Europe : un problème sans issue

Ugo Rossi

\section{Introduction}

\begin{abstract}
Although north-central Europe has suddenly developed an acute case of amnesia, a few years ago the financial press was praising Spain, Portugal and even Greece (plus non-EU Turkey) for their competence in trimming public spending and boosting growth rates. In the immediate aftermath of the Wall Street debacle, the fears of the EU had been principally focused on Ireland, the Baltic and Eastern Europe. The Mediterranean as a whole was perceived as relatively well protected from the financial tsunami crossing the Atlantic at supersonic speed (Davis, 2011, p. 10).
\end{abstract}

1 As Mike Davis points out, Southern European countries have been "late comers" in the process of economic crisis affecting the world economy since 2007, subsequently becoming the epicentre of the global economic turmoil. In its early stages, the crisis was concentrated in the US economy, where the subprime mortgage crisis began in 2006-07 giving rise to an unprecedented financial turmoil in the era of globalisation and a consequent wave of economic slump and stagnation across the world: the so-called "Second Great Contraction" in recent capitalist history, after the "First Great Contraction" or Great Depression as is commonly know that followed the 1929 banking crisis (Reinhart and Rogoff, 2010).

2 As soon as the crisis "infected" the financial sector, since late 2008 the "epidemic" rapidly spread to other capitalist regions across the globe, including those European countries that in previous years had been particularly exposed to processes of financialisation of 
their fast-growing economies : Ireland, Iceland, Greece, Spain and in a minor way also the Baltic and East-European countries. Since the early 1990s, when global markets were in the middle of the impetuous process of geographical expansion that academic researchers had started to define in terms of "globalisation" (Dicken, 2011), these economies have been heavily penetrated by foreign banks and international capitals, following processes of market deregulation and liberalization at national and international levels. However, since mid-2010, the financial epidemic has begun to seriously threaten other countries in Southern Europe, such as Portugal, Italy and most recently France, while countries at Northern latitudes - such as the Baltic countries and Iceland, but not Ireland which has remained part of the so-called PIIGS circle - have been more successful in revamping their economies, managing to re-enhance their competitiveness, at least according to conventional economic indicators such as GDP growth and foreign direct investment.

3 In the second phase of the global recession (2010-12), the epicentre of the global economic recession has become, therefore, Southern Europe, where the crisis has taken the form of a sovereign debt crisis : for one indicator or another, Spain, Greece, Italy and Portugal (and partly also the more solid France) are all countries whose economies are under the threat of default and collapse and for this reason they are at the centre of international debates about the global economic crisis. Along with the problem of national indebtedness, which menaces to force them to leave the Eurozone, the advent of the crisis has exacerbated social problems and economic weaknesses historically affecting these countries: high unemployment rates, female participation in the labour force persistently below the EU average, low social mobility, persistent and even deepening regional imbalances, high mortality rates of firms, amongst the others. In these economically fragile contexts, large cities play an ambivalent role : on the one hand, they tend to attract the few innovative economic activities in these regions (from capitalintensive and high-tech firms to research centres and advanced business services); on the other hand, they are also places where social tensions are most evident and where local economies exhibit their contradictions: a hypertrophic public sector where relations of clientelism and political patronage are still predominant; the persistence of parasitic industries surviving thanks to state subsidies; insufficient infrastructure endowment; obsolescence of urban planning policies and regulations. Altogether, these and other structural problems and distortions frustrate the socio-economic potential of these regions, preventing the achievement of a socially inclusive development path and generating phenomena of environmental degradation and citizens' distrust in public institutions.

4 The case of Cagliari and the ways in which this city has been affected by the global economic crisis is illustrative of this broader politico-economic context. Before exploring this case-study, the paper will analyse the distinctive features of neoliberalism in Italy and in the Southern Italian context. The paper will be structured as follows : in the first section, we shall scrutinise the distinguishing features of neoliberalism in Italy and the Italian Mezzogiorno; in the second section, after having shortly presented a politicaleconomic profile of Cagliari and the Sardinia region, we shall outline the ways in which the global economic crisis has manifested in this city in the form of a variety of protest movements using the urban space as a place of encounter. Finally, in the conclusion the paper will reflect on the future of neoliberalism and Southern Europe. 


\section{Neoliberalism at the margins of Europe}

5 It is now widely accepted within the critical social sciences to view neoliberalism as a mobile and hybrid technology of government (see Ong, 2007), constantly travelling across the globe and, in doing so, fusing with local cultures of governance, entrepreneurship and socio-economic agency. The mobility, contingency and spatiotemporal variegation of neoliberalism have been widely debated by critical social scientists over the last twenty years, particularly with reference to urban and regional development pathways (Wilson, 2004; Brenner, Peck and Theodore, 2010). In this specific perspective, scholars have placed emphasis on cities as sites where neoliberalism as a mobile technology materialises in more visible ways : more than any other spatial setting, in the era of globalisation and postmodernity cities have acted simultaneously as spaces of representation (as sites of hallmark events and iconic architecture), government (as crucial scales of subnational governance) and contestation (as incubators of social movements) for neoliberalism as a mode of regulation and capitalist accumulation (see Rossi and Vanolo, 2012).

6 In light of increasingly generalised assumptions about the contingency and variegation of neoliberalism in time and space, a burgeoning literature dealing with the manifestation of neoliberalism in an increasing variety of geographical settings has developed in recent times. While there is panoply of contributions dealing with the emerging economies of Asia and South-America, it is surprising to notice the paucity of literature investigating neoliberalism in what was once said to be a major example of "semi-peripheral region" in the capitalist world economy: Southern Europe (Arrighi, 1985). This scarcity is particularly evident in the case of Italy and even more in the South of Italy, the so-called Mezzogiorno, once a highly investigated example of uneven regional development in a semi-peripheral context. In the light of this state of affairs, a number of questions arise : is Italy a neoliberal economy? And, if it is so, what kind of neoliberalism does this country exemplify? And what about the Mezzogiorno and the long-standing North-South divide? In the next section of this paper, we shall attempt to answer these questions, by analysing the distinctive features of neoliberalism in Italy and the position occupied by the Mezzogiorno in the described politico-economic context.

\section{Italy : concerted neoliberalism}

7 While in the major Anglo-Saxon countries the rise of neoliberalism as dominant mode of regulation traces back to the early 1980s, in Southern Europe and elsewhere the shift from Keynesian modes of regulation to specific forms of neoliberalism has occurred largely in the subsequent decade.

Italy is not an exception to this chronology. It is in the early 1990s that this country started shifting towards the neoliberal mode of economic governance and regulation. A decisive turning-point in this evolution of Italy's economy and politics is represented by the political-economic crisis of 1992. In political terms, in 1992 Italy witnessed the opening of a groundbreaking judicial enquiry, denominated Mani Pulite (or Clean Hands), which began in Milan (Italy's economic capital) and then spread to other regions. The inquiry brought to light the widespread corruption within the political system, eventually leading to the crisis and decline of the First Republic (the post-war Republic). 
In economic terms, in the same year Italy was hit by what has been known for many years as the "big crisis" in this country, at least until the global economic crisis of the late 2000s. Italy's economic slump in 1992 was linked to a broader currency crisis occurring at the European level within the framework of the then operating European Monetary System (later replaced by the Eurozone). Direct effect of the crisis was the devaluation of the national currency, which forced Italy to withdraw from the European Monetary System (along with the UK). The other side of the coin of this unpleasant decision was that the depreciation of the national currency allowed Italian small and medium-sized enterprises (Italian manufacturing system is largely composed of small companies, as the literature on the Third Italy has documented in previous years) to temporarily enhance their competitive position within the international economy, because Italian products could be sold at lower prices abroad. However, the monetary incentive to increase exports was not sufficient to revitalise the Italian economy, which was burdened by an unsustainable government debt (around 100\% of GDP). The economic crisis urged the Italian government (at that time led by technocrats as the major political parties had been involved in the judicial enquiry) to approve a budget law containing a series of austerity measures that were intended to improve Italy's competitiveness and fiscal balance : increase in pension age, removal of the so-called "sliding scale" (or scala mobile) linking wage rates to product prices, introduction of fees for health services provided by hospitals, privatisation of government-owned companies, amongst the others. At the time of writing (summer 2012), similar measures have been adopted, or are in the process of being adopted, by another technocratic government nominated in December 2011 in order to deal with a comparably difficult economic situation originally caused by the international financial crash of 2008-09.

9 Beyond contingent initiatives aimed at short-term economic recovery, the year 1992 thus represents the point of departure for Italy's transition towards a neoliberal governance of the economy. At the institutional level, the neoliberalisation of the Italian economy has been based on a pact of collaboration between national government, trade unions and the employers' organisations. Austerity policies were agreed with the unions through the socalled "concertation process". This consensus-led approach to economic reform and restructuring implied that government had to coordinate the decision-making process with the trade unions, thus avoiding conflict and opposition. However, in several marches and assemblies organised in response to austerity policies, leaders of the major unions were severely contested by workers concerned about the pensions reform and the wage restraint policy. Even in the presence of growing social discontent, the so-called "concertation method" has continued to lead the process of economic reform, particularly in the labour market, for almost a decade. The unity among trade unions came to an end only during the Berlusconi government in the first half of the 2000s (the longest in Republican Italy) when the left-leaning trade union (CGIL) dissociated itself from labour (de)regulation agreements subscribed by the other two major unions (the catholic CISL and the social-democratic UIL).

However, despite recent disagreements, trade unions have jointly played a central role in the transition towards "concerted neoliberalism" in Italy. As a result, from 1992 onwards, the neoliberalisation of the economy proceeded smoothly in a context of apparent "social peace", radically restructuring class relationships and the dynamics of social conflict in Italy. In particular, two have been the pillars of the neoliberalisation of the Italian economy and society : the flexibilisation of the labour force and the deregulation of the 
housing market. The flexibilisation of the labour force has been pursued through subsequent legislative acts approved by the Parliament accepting reform proposals advanced by both centre-left and centre-right government coalitions between 1995 and 2004 and most recently in June 2012. Flexibilisation soon turned out to be a pure "precariousisation" of the labour force, as the introduction of temporary contracts has not been accompanied by social security provisions and benefits for the causalised workers. As a result, since the mid-1990s the precariousness of the workforce - especially of its younger cohorts - and the related dualism of the labour market have become the phenomena that in many respects best illustrate the malaises and contradictions of Italian society (see Molé, 2010).

11 The second pillar of neoliberalism in Italy has been the housing sector. The supply of public housing has decreased by about $20 \%$ between 1991 and 2007, amounting only to the $4 \%$ of the occupied housing stock in 2010 (Nomisma, 2010). In the past, the historically limited supply of public and subsidised housing in Italy was compensated by legislation aimed at keeping rental prices affordable for disadvantaged groups in the private property market. The so-called "fair rent" act was approved in 1978 with this purpose. However, legislative acts passed by the Parliament in 1992 and 1998 (the latter by a centre-left majority) gradually neutralised the "fair rent" policy, rendering it de facto inoperative in recent years. As a result of this twofold process - the shrinkage of public housing supply and the neutralisation of regulations making the private rental sector more affordable - Italy has become a nation with a record number of homeowners : in 2010 , two years after the end of the housing bubble of the 2000 s, the $84 \%$ of households were owner-occupiers. For many years, the conventional wisdom has portrayed Italian families as tireless savers and far less indebted homeowners compared with their counterparts in other capitalist countries, as home buyers are accustomed to rely on safe intra-family loans in Italy. This reassuring picture of socially cohesive and almost universal homeownership was disturbed in late 2010 by the alarming publication in Italian newspapers (see, for instance, La Repubblica, 2010) of the findings contained in a research report by the Bank of Italy, which showed that the so-called "mortgage delinquency rate" steadily increased amongst mortgaged Italian households between 2000 and 2007 (up to the 5\%), thus already before the financial crisis, and that Italians are ranked at the top of the credit risk list along with Spaniards in Europe. Social groups that are most exposed to credit risk are those who have lost their jobs after stipulating a mortgage, but also single parents, low-income workers and the expanding category of temporary ("precarious") employees (Banca d'Italia, 2010). Job precariousness and unequal access to housing are thus closely interrelated phenomena shedding light on the contradictions and inequalities that have arisen from the neoliberalisation of the Italian economy over the last two decades.

While the labour market and the housing sector have been subject to a relatively smooth process of deregulation, privatisation and liberalisation reforms have proven more problematic. In some cases, these reforms have found the opposition of professional and elite power groups (those with closer links with members of Parliament) : from the powerful liberal professions (lawyers, pharmacists, dentists, etc.) to the less affluent categories of independent contractors and retailers (taxi drivers, tobacconists, newsagents, etc.). The privatisation of government-owned utility and infrastructure companies has been more straightforward but is still underway and with contested outcomes: between the first half of the 1990s and the early 2000s telephone, energy, 
motorway and railway state-owned operators were privatised, entirely or partly as the state has remained the majority shareholder in some cases (such as that of ENI, the multinational oil and gas company and Italy's best positioned firm in annual rankings of world's biggest companies). Particularly contested has been the privatisation of the motorways and train operating companies, as profit-led economic imperatives have appeared to prevail over the public function of these services. In December 2011 the railway operating company unilaterally decided to suppress night-train routes historically connecting the Southern to the Northern regions, still widely used by domestic migrants and long-distance commuters for their affordable fares. At the same time, investments in motorways and other infrastructure in the South have remained weak and inadequate, while spectacular infrastructure projects (whose social utility, however, has always been unclear) such as the bridge that should link Sicily to mainland Italy across the Strait of Messina are repeatedly announced but never commenced. This occurs also because EU's financial support to infrastructure projects has effects at intraregional and in fewer cases inter-regional levels but not at a national level as they are confined to the less-favoured regions in the South.

In conclusion, the retreat of the state and the related wave of privatisations have deepened the infrastructure marginalisation of the Southern regions in Italy. This leads us to zoom our analytical focus on the Mezzogiorno and the North-South divide historically characterising Italy's economic geography.

\section{The supposed end of the Southern Question}

14 The material disconnection of the South from the North of Italy (the increased sociospatial selectiveness of inter-regional transportation services and the widening infrastructure gap) has special significance. As in all economically "backward" regions, infrastructure endowment has historically been a key issue in debates about regional inequalities and related policy initiatives. When post-war Italy started a regional policy denominated "Extraordinary Intervention", which drew inspiration from Roosevelt's "New Deal" in the USA, infrastructure policies were placed high on the agenda during the so-called "pre-industrialisation phase". Extraordinary Intervention indeed started in the 1950s focusing on public works in agriculture (land reclamation, irrigation systems, etc.) and the transportation sector (construction of motorways, railways, etc.). In subsequent decades, Extraordinary Intervention started grappling with the production sectors themselves, such as the industry most notably, even though specialists of the "Southern Question" agree that the early "infrastructural stage" of the programme was the most successful and effective in terms of support to economic development pathways at the regional level (see Rossi, 2002). Between the mid-1980s and the early 1990s, Italian governments put an end to the Extraordinary Intervention, terminating the Cassa per il Mezzogiorno (or Fund for the Mezzogiorno) that had been established in 1950 in order to cope with the implementation of this policy. The ending years of the Programme had been particularly characterised by the clientelistic management of public expenditure, such as in the case of the programme supporting the physical reconstruction of the areas hit by the earthquake in the Campania region. In 1992, a turning-point also in this respect, the Agenzia per il Mezzogiorno - as the Cassa per il Mezzogiorno had been renamed in 1984 - was dismantled. After about thirty years of intervention, a mixed picture of successes and failures took shape: on the one hand, the Mezzogiorno appeared to have undergone an unprecedented process of transformation, especially in terms of 
infrastructure endowment; on the other hand, however, the state-led intervention programme ended up fostering phenomena of clientelism and corruption. In the last instance, this degeneration delegitimised the role of state expenditure in tackling the North-South divide, offering the opportunity for starting a process of neoliberalisation as the previous section has showed (see Martinelli, 2009).

After the unraveling of the Keynesian policy of Extraordinary Intervention, in the second half of the 1990s the South of Italy found itself in the middle of a difficult economic transition. In 1996, the centre-left government launched a new policy initiative named "Negotiated Planning" (Gualini, 2001), which aimed at sustaining processes of local economic development in the southern regions based on forms of collaborative planning and negotiated decision-making at the institutional level and on the revitalisation of local economies and particularly of embryonic industrial districts reproducing forms of local economic development associated with the so-called Third Italy model : policy initiatives called "Territorial Pacts" are an example of this regional development policy that lasted until the early 2000s.

The success of this neo-institutionalist and post-Fordist approach to the economic development of the Mezzogiorno has been limited in terms of wealth and employment locally generated (Rossi, 2004). The perceived failure of the new programme of regional policy based on the stimulation of endogenous growth has generated a new wave of disillusionment towards policies specifically addressing the economy of the Mezzogiorno understood as a unitary politico-geographical entity. This has led influential commentators to make pleas to "abolish the Mezzogiorno" (Viesti, 2003) and to call for a broader vision putting the Mezzogiorno in the Mediterranean context by paying renewed attention in terms of policy strategies to infrastructure and particularly to the logistics sector (N. Rossi, 2005). While the Southern Question became delegitimised owing to its own - perceived or real - failures, the same decades (the 1990s and the 2000s) have witnessed the rapid political ascent of the Lega Nord in the most prosperous parts of the country, fostering explicitly anti-Southern sentiments and calling for politico-economic devolution if not secession from the national state. Even though regional disparities between the North and the South of the country were persistent and in some respects even widened during these decades, the alleged Northern Question - with representatives of small and medium-sized businesses in the forefront of the devolutionist political movement - has gained increasingly wide currency within the general public.

While the discontent of the most affluent regions of the country came to the fore in public debate in the 1990s and the subsequent decade, the deprived regions of the South were confined to debates focusing on technical issues falling within the post-political realm of the European multi-level governance system. In conclusion, the transition to neoliberalism in Italy has implied a simultaneously geographical and politico-economic shift of attention from the less favoured to the most prosperous regions of the country. The neoliberal paradox characterising Italy in the last two decades has therefore produced a reversed map of policy priorities and concerns compared with the Keynesian times of the post-war decades. 


\section{An island in the storm : the global economic crisis in Cagliari and the Sardinia region}

Over the last two or three years, the Sardinia Region has attracted growing attention of Italy's general public in the news concerning the effects of the global economic crisis. Since 2010, Cagliari - as the regional capital of Sardinia - has witnessed a growing outburst of social discontent, taking the form of frequent street demonstrations led by a variety of social groups : industrial workers threatened with losing their jobs; shepherds and independent farmers affected by the deepening of the already ongoing agricultural crisis; small entrepreneurs and independent contractors struggling to survive, amongst the others (see below in this paragraph a more detailed description of these protest movements). In their demonstrations, many of these protest movements have attempted to stage occupations of local government's headquarters and key public spaces in Cagliari. For a region that in the last years built its reputation as a "tourist paradise", it has been doubly inconvenient to associate its image with one of crisis, socio-economic suffering and mass protest.

Sardinia's situation is not exceptional in the Italian and the larger South-European contexts, as we have seen in the previous paragraphs of this paper. However, while other regions in the South of Italy have also seriously suffered the consequences of the crisis, the Sardinia region seems to have been especially affected by the global economic slump. This situation appears to be in contrast to conventional economic indicators, such as the GDP above all, which place Sardinia at a slightly higher position in terms of growth performances with respect to the other regions historically forming the Mezzogiorno. Indeed, in the current round of EU regional policy (2007-13) Sardinia has gained the status as phasing-in region, while the other Southern regions are either phasing-out or convergence regions, which means that their GDP is ranked at a lower position than the average of the enlarged EU. In particular, recent data show that the poorest regions in the South are Sicily, Campania and Calabria, the former two being also the most populous regions in the South.

20 It is beyond the scope of this paper examining the causes of these regionally uneven "catch up" processes in the South of Italy, to put it in the conventional lexicon of development studies. However, it is worth noting that the three worst-performing regions in the Mezzogiorno are those whose economies and societies have been most heavily affected by the presence of organised crime : the Mafia in Sicily, the "Ndrangheta in Calabria and the Camorra in Campania. From this point of view, Sardinia has been historically characterised by the absence of significant criminal gangs organized on a permanent basis, apart from the phenomenon of kidnapping that was widespread in the mountain areas of the region still in the 1980s but has disappeared in recent times. The lack of crime and the relatively low demographic pressure (compared to densely populated regions such as Sicily, Campania and Puglia, Campania having the highest fertility rates at the national level) has allowed Sardinia to retain a slightly wealthier condition in the Italian South.

21 At the same time, Sardinia's peripheral and isolated location has produced a common sense and related geographical imaginary of wilderness particularly associated with its unspoilt inland areas (see Heatherington, 2010), but also defining the identity of the region as a whole. As a result, being conventionally known for the structural weaknesses 
deriving from its insularity (particularly in terms of transport connections to the mainland as well as of limited energy supply), today's Sardinia is also customarily regarded in a more positive light as a mostly uncontaminated region. An increasingly commonly held view indeed maintains that this peripheral positionality entails the potential to turn Sardinia into an emblem of environmentally sensitive region on a large scale. Even so, apart from the flourishing but persistently seasonal tourist sector, whose environmental sustainability however is dubious at least (being concentrated along the coast), the economy of the island still draws a great part of its subsistence from the conventional (highly polluting) industrial sector such as refineries and chemical plants located both in the North and the South of the island.

In this context, due also to its own peripherality at the regional level, being located in the far South of the island, Cagliari has historically played the role as a merely administrative centre within the framework of the top-down, hierarchical structure of regional government. In the post-war decades, Cagliari and its larger urban conglomeration coinciding with the province's tier level of government was also targeted by the policy of growth poles enacted within the framework of the previously mentioned Extraordinary Intervention programme (see Rossi, 2009). Located in the Westsouthern part of the region, the growth-pole of Portovesme, which specialises in metalworking processes (especially aluminium), is still active, even though it has become one of the most problematic areas in the region well before the 2008-09 global crisis. In January 2012, Alcoa - the third world's leading firm in the aluminium industry, with headquarters in Pittsburgh (Pennsylvania), employing around one thousand workers in Portovesme - has announced the closure of its Sardinian plant, along with those in Spain (see more below). Located even closer to Cagliari (only $25 \mathrm{~km}$ from the city centre) is another industrial giant : the oil refinery of Sarroch founded in 1962 by Milanese entrepreneur Angelo Moratti and still owned by his heirs, currently employing 1800 workers (the largest employer in the private sector in the region). While this industry enjoys relatively good health in terms of profits and market shares, its location is highly problematic in environmental terms, as its carbon emissions affect the environment of a diffusely populated area (the Southwestern part of Cagliari's urban region) close to the renowned tourist destinations of Pula and Chia.

While there is widespread conviction that the mature, externally owned industrial sector is bound to disappear and relocate elsewhere sooner or later, greater expectations have been formed with regard to local economic development in recent times. The Mid North of Sardinia has seen the rise of a still limited number of endogenous industrial districts, such as the natural cork district in Calangianus (near Olbia) and the textile district of Macomer, the latter however being heavily affected by the crisis of this sector since 2005 . Southern Sardinia (where Cagliari is located), on its part, lacks industrial districts and other forms of locally embedded manufacturing systems. The weakness of local industry has also prevented the South of the island from seizing the opportunity to become a logistic hub in connection with the development of the maritime economy, following the foundation of the Cagliari International Container Terminal in the late 1990s. Originally presented as an ambitious project potentially transforming Cagliari into a "gateway city" in the Western Mediterranean (see Short et al., 2000), having experienced a number of vicissitudes in the pre-crisis period, the Cagliari port container has remained a mere transshipment hub failing to territorialise itself by establishing trade-production connections with the local economy (Boggio, Memoli and Rossi, 2008)2 ${ }^{2}$. 
the other hand, however, in recent years the urban area of Cagliari has seen the rise of two post-Fordist industries: the internationally renowned telephone and internet services provider Tiscali, formed in 1998 and owned in majority by Renato Soru, a charismatic entrepreneur who was subsequently elected head of a centre-left regional government in 2004 (holding this position until 2008); and since its foundation in 1990 the publicly funded science and technology park, called Sardegna Ricerche, specialising in applied research covering the fields of biomedicine, energy and the environment and information society. Taken together, the ICT industry and the science and technology park currently have around 1000 employees, even though in recent years the former has faced a process of restructuring as a consequence of reduced business activity and financial stability. In the 2000s, the regional government has invested a large amount of European funds in initiatives aimed at enhancing the Research and Development sector in Sardinia, some of them have been widely regarded as innovative, being also imitated by other regional governments in Italy, such as the "Master and back" policy by which Sardinian students had the opportunity to attend postgraduate studies outside the island and then to come back for an internship period.

It is against the backdrop of this socio-economic context, which is due to Sardinia's insularity but is also exemplificative of uneven regional development patterns and dynamics in Southern Europe, that one has to understand the manifestation of the global economic crisis in the city of Cagliari and in the island as a whole. The examples reported above show that crucial sectors of the Sardinian economy have been affected by processes of crisis and decline already in the mid-2000s, thus before the manifestation of the global economic crisis. The agricultural crisis particularly affecting shepherds and independent farmers, the decline of the textile district in Macomer, the shrinkage of the ICT business in Cagliari and the closure of plants in the growth pole in Portovesme : all these events date back to the pre-crisis years. The majority of the "qualified informants" 3 that have been interviewed for this research project have underlined the preexisting crisis condition in Sardinia. At the same time, they have also noted how "The Crisis" - the global economic crisis - has arrived late in Sardinia compared with regions in Europe that are more centrally positioned in both geographical and economic terms. This delayed manifestation of the crisis is not specific to Sardinia, but it has to do with Southern Europe as a whole, which initially appeared to be only peripherally touched by the economic downturn of 2008-09 hitting the more financialised economies of North America and North-Central Europe (cf. Mike Davis's quotation in the introduction to this paper).

grovided a picture of the regional and urban economic context in which the global crisis has intervened, the coming sections of this paragraph will present the social protest arising from the crisis that has taken shape in Cagliari in recent times.

\section{The crisis, the city, and the politics of encounter}

Since 2010 the city of Cagliari has played a central role in the crisis as a place of gathering for a variety of local protest movements organised by social groups particularly affected by the crisis. Two aspects deserve attention with respect to these protest movements : first, most of the social groups that have given rise to these movements are not physically located in Cagliari, even though they have chosen this city as a place for their demonstrations ; second, the majority of these movements were already in the process of 
formation before the crisis but then have been erupting as soon as the crisis has taken shape. The crisis, therefore, becomes a catalyst for social discontent, while the city allows protest to happen.

The first aspect - which can be defined as the urbanisation of protest movements (in Cagliari) originating from elsewhere (other areas of Sardinia) - is illustrative of what Andy Merrifield (2011) has recently argued in his reflection on the legacy of the political struggles and insurgent movements that erupted across the world in 2011 : from the Arab Spring in North Africa and the Middle East, to the Occupy Wall Street campaign in North America and the movement of Indignados in Spain. In his article, Merrifield points out that - despite the apparent de-materialisation of collective mobilisation and the emphasis commonly laid on immaterial networks of communication (Facebook, Twitter, etc.) these struggles show how the city remains a crucial site of political action in the contemporary world, even beyond the claiming of the right-to-the-city itself. Put it differently, these mobilisations prove that the city is a common space where "here comes everybody" producing an encounter capable of reconciling a variety of senses of belonging and identity with the universalism of claims and social needs. It is in this perspective that local protest movements in Cagliari can be understood. In particular, five protest movements have erupted since "the crisis" started in 2010: I) shepherds and independent farmers; II) retailers and contractors; III) truck drivers; IV) industrial workers; V) civil-society organisations.

\section{Shepherds and farmers : losers of the "single market"}

The movement of independent farmers traces its origins back to the 1990s, when the Italian Parliament approved a law implementing a European Union's directive by which nearly five thousand Sardinia agricultural firms had illegitimately received subsidies from the regional government (judged as "state aids" distorting market competition) and thus had to give the money back to the state. After prolonged struggles and confrontation, in October 2011 the regional government announced that the payment of these debts was temporarily suspended following an agreement with the EU institutions. However, while the crisis linked to the indebtement has been partially resolved, the effects of the global economic crisis have hit the agricultural sector in Sardinia : in 2011 and 2012 there has been an increase in agricultural firms being forced to close.

While the regional scene has been occupied for many years by the struggles of the indebted farmers, recent years have seen an intensification of protest led by shepherds as a consequence of the "structural crisis" affecting the agricultural sector . The movement of shepherds in Sardinia has developed under the banner of the Movimento Pastori Sardi (Movement of Sardinian Shepherds), a regional organisation independent from national unions in this sector (accused of being insensitive to local and regional needs), whose origins also date back to the 1990s. Sardinian shepherds lament the unfavourable market conditions affecting small-sized diary farms (in particular, the high price of locally produced sheep milk, Sardinia being Italy's major producer of Pecorino Romano along with other local varieties of sheep cheese). Since late 2010 this movement has given rise to a heated protest culminating in repeated street riots, the most violent of which occurred in Cagliari in October 2010, when the shepherds tried to occupy the headquarters of the Regional Council (the elective legislative body of a Region in Italy). At the end of December 2011, the regional government announced that European funds in 
support to Sardinian agriculture had been increased up to 160 million euro, doubling those received only two years earlier. This inflow of money has been intended also to calm protests, even though at the time of writing (summer 2012) it is still early to evaluate its effect. The crisis of agriculture - a sector having great potential in the Sardinia region - is also closely related to the broader food crisis at the global level, which is one of the factors behind the recent wave of rebellions and revolutions in North Africa and elsewhere across the world (Holt-Giménez and Patel, 2009).

\section{Retailers and artisans : victims of privatisation}

The movement of small retailers and artisans has developed under the banner of the independent Movimento Artigiani e Commercianti Liberi Sardegna which has taken shape since 2011 in the region of Sulcis-Iglesiente, the area in Southwestern Sardinia that has most suffered the consequences of the crisis. The movement formed in response to the imposition of onerous fiscal penalties associated with tax evasion. For many years, small fiscal infractions were tolerated in Italy, especially in the deprived South, but after the privatisation of tax collection they have been severely sanctioned. For its allegedly persecutory methods (insolvent taxpayers not paying the fines are threatened with legal sanctions eventually leading to property foreclosure), the privatised agency Equitalia has become a usual target of social discontent in Sardinia and elsewhere in Italy.

The anti-penalties movement has gained visibility following a mass demonstration organised in Cagliari in late July 2011, jointly with the movement of shepherds. This unusual alliance was joined by the truck drivers in January 2012 within the framework of the so-called Movimento dei Forconi Sardi (Sardinia Pitchfork Movement), which will be analysed in the subsequent section.

\section{Truck drivers : the moving protestors}

34 The movement of truck drivers has taken shape for the first time in July 2011 under the aegis of the newly formed Sardegna in Movimento (Sardinia in Movement) association. At the time, truck drivers occupied the harbour of Olbia in the North-East of the island (the busiest port in Sardinia for passengers and goods connecting the island to mainland Italy), protesting against the rise in transportation costs imposed by private maritime companies operating under conditions of de facto monopoly.

However, it has been in January 2012 that the truck drivers movement has attracted the attention of the wider public in Italy, when it gave rise to the Sardinian version of the socalled Movement of Pitchforks that took originally form in Sicily, leading to the blockade of Italian motorways for an entire week with severe repercussions on the national economy. In Sicily, truck drivers started protesting against the increase in fuel price, receiving solidarity and support from college students and other spontaneously organised groups fed up with the corruption of politicians, but also accusations of populism and coercive methods of protest. The Sardinia Pitchfork Movement organised the simultaneous occupation of two key sites of the port of Cagliari : the artisans and retailers were protagonists of the occupation of Molo Ichnusa, the newly built cruise ship terminal in the historical harbour of Cagliari located just in front of the headquarters of the Regional Council (a frequent target of protest movements in Sardinia : see section I. in 
this paragraph), while the truck drivers took the lead in the occupation of the commercial and industrial port in Macchiareddu, in the Eastern part of the bay of Cagliari.

\section{Industrial workers : remnants of the growth-pole era}

In Italy, Sardinian workers employed by Alcoa, a US multi-site company specialised in the production of aluminium, started to become a symbol of struggles against the crisis when their demonstration in Rome was severely repressed by the police in November 2009. At the time, fearing the same fate as Eurallumina, the Russian company specialising in the production of bauxite and aluminium that closed its plant in Portovesme in March 2009, Sardinian workers took to the street to protest against the risk of closure for Alcoa's Sardinian plant.

About only one year later, in early January 2012 the closure has materialised: Alcoa's executive office in Pittsburgh publicly announced the permanent closure of its plants in Sardinia and in Spain caused by the rising cost of raw materials accompanied by the falling prices of final goods in the aluminium sector as well as by the rising operating cost (particularly the electric energy whose price is higher in Italy compared with other countries). Following this decision, Alcoa workers have taken to the streets again, joining the other protest groups and giving rise to an unusual coalition (the previously mentioned Sardinian version of Pitchfork Movement) which brings together social actors that until the recent past preceding the advent of the crisis it was hard to imagine standing together. Finally, in August 2012 - amid peak tourist season - Alcoa workers have occupied the roads leading to the airport of Cagliari, forcing tourists to get to the departure terminal on foot.

\section{Post-industrial future denied : the Geomineral Park at risk of closure}

Following previous UNESCO recognition in the late 1990s, the Geomineral, Historical and Environmental Park of Sardinia officially started operating in 2001. As a recognition of its outstanding mineral heritage, the Sulcis-Iglesiente region in Southwestern Sardinia comprises almost half of the Park's surface area : the mining industry has been still active in this region until the 1960s and up to the 1940s it was the second largest industry in Italy following FIAT's automotive industry (eighteen thousand employees in the Carbonia area in the 1940s). While industrial companies in this region - those in the Portovesme pole - are threatened by the effects of the crisis and some of them have already closed such as Alcoa, local population expected that the establishment of the national Park could open the way for the transition to a post-industrial future which however has never taken shape. In fact, after ten years since its founding, the National Park runs the risk of closure. Alarms about the Park's closure started in the Summer of 2011, eventually leading employees of the Park along with nonprofit organisations to stage demonstrations and permanent sit-ins at the headquarters of the Presidency of the Regional Government in Cagliari. In January 2012, Park employees have expressed solidarity with Alcoa workers and other groups involved in street protests across the region. 


\section{Conclusion}

Cagliari and the Sardinia region are illustrative of the way in which the global economic crisis has affected the "real" economies of peripheral regions in Southern Europe, hitting the whole spectrum of economic sectors : from the residual large scale industries to small firms in agriculture, retail and transportation and even the most promising environmentalist and post-Fordist economies. Since 2010 the structural crisis of Southern Europe has increasingly attracted the attention of the general public and political leaders in Europe and across the world, after the explosion of the sovereign debt crisis in Greece and, to a lesser extent, in Portugal, Spain and Italy. While mainstream opinion-makers have associated the crisis with the undisciplined public spending of the previous years, critical commentators have pointed to the distorted development pattern prevailing in Southern Europe based on a perverse combination of construction-led growth, inadequate investment in technological innovation and unlimited flexibilisation of the workforce in the absence of both social guarantees and job mobility.

The case of Cagliari and the Sardinia region thus provides empirical evidence of the contradictions arising from the neoliberalisation of peripheral Southern European economies, which have led to the eruption of social discontent as a reaction to the apparent lack of credible economic-political alternatives. In this context, promises of an environmentally sustainable development for the Southern regions of Europe turn out to be mere consolations and rhetorical expedients supporting the views of those looking at the future of Southern Europe as a merely leisure-oriented society. Recently, in the Wall Street Journal conservative historian Niall Ferguson has forecasted that in ten years' time Southern European countries will become a "vacation land" for industrious Northern Europeans looking for rest and sunbath (see figure 1).

Figure 1. The New Europe according to Niall Ferguson.

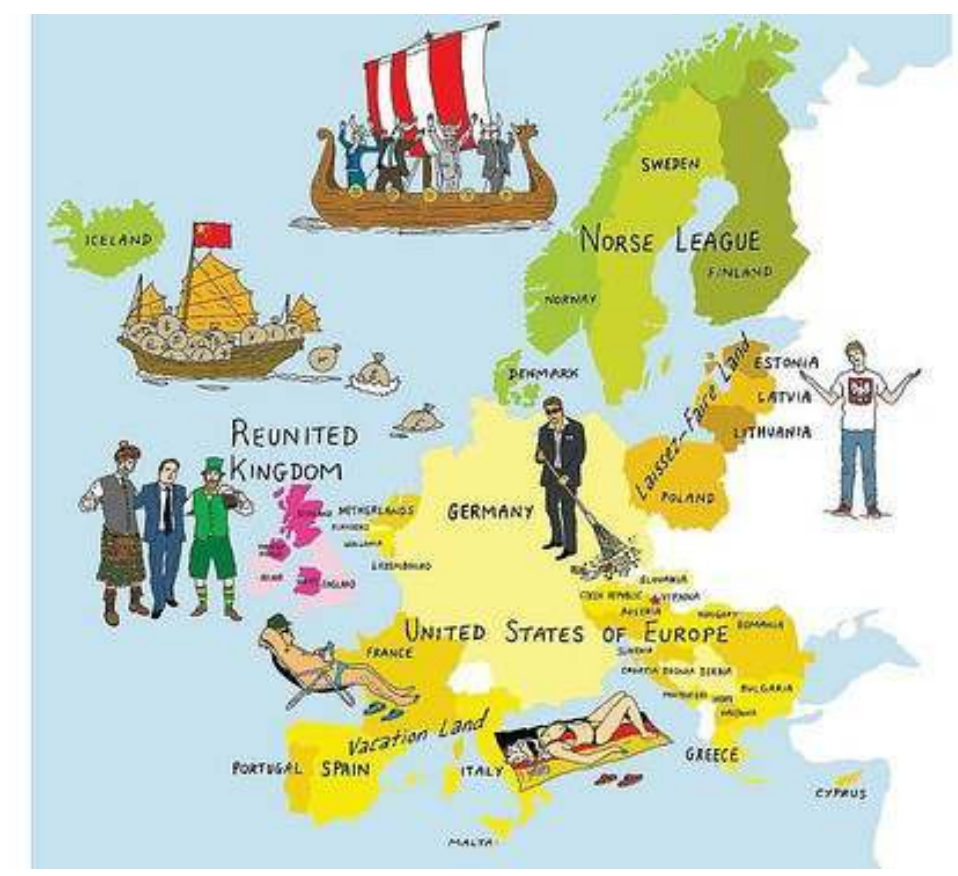

SOURCE : THE WALL STREET JOURNAL (NOVEMBER 2011). 
41 For this reason, the story of Sardinia tells us about the future of Southern Europe as a whole. In previous decades, this region embarked on a variety of development pathways, each one reflecting the "spirit of the times" in the conventional wisdom of regional economic planning and policy : the growth pole strategy in the 1960s and the early 1970s, the discovery of the "tourism opportunity" in the 1980s, the rise of the post-Fordist industry (endogenous districts and technological firms) and the environmentalist economy in the 1990s and in the last decade. However, following in the wake of the repeated failure of conventional recipes for economic growth, the global economic crisis is shattering the remaining expectations of economic prosperity, while the harshest austerity measures are being implemented on the grounds that there's no hope for recovery if national governments and local administrations do not obey the dictates of international financial institutions and monetary authorities. In this context, even though in Southern Europe there are still social groups that react to this situation resorting to collective action and inter-group solidarity, as this paper has shown, the vast majority of the population become increasingly discouraged and unhopeful for the future, choosing either to emigrate or to rely on clientelistic networks and social class privilege. In this context, a politics of resistance does not suffice for Southern European societies to get out of this iron cage of financial neo-colonialism, on the one hand, and of social resignation and opportunism, on the other hand. An imaginative politics of renaissance is needed at a cross-South-European scale. The point of departure for this politics of renaissance will have to deal not only with the failures of neoliberalism as a politico-economic doctrine but also with the possibility to embrace a radically reformed European project in search of a renewed sense of socio-spatial justice and solidarity amongst unevenly developed regions (cf. Hadjmichalis, 2011).

\section{BIBLIOGRAPHY}

ARRIGHI G. (ed.) (1985), Semiperipheral Development. The Politics of Southern Europe in the Twentieth Century, Beverly Hills, CA, Sage Publications.

BOGGIO F., MEMOLI M. \& ROSSI U. (2008), “Attori locali e strategie di sviluppo urbano a Cagliari : la contesa sulla portualità”, in SOMMELLA R. (ed.) Le città del Mezzogiorno. Dinamiche, politiche, attori, Milan, Angeli, pp. 157-172.

BRENNER N., PECK J. \& THEODORE N. (2010), “Variegated neoliberalization : geographies, modalities, pathways", Global Networks, 10, 2, pp. 182-222.

DAVIS M. (2011) “Spring confronts winter”, New Left Review, 72, pp. 5-15.

DICKEN P. (2011) Global Shift. Mapping the Changing Contours of the World Economy, New York, Guilford Press (6 ${ }^{\text {th }}$ edition).

FERGUSON N. (2011), “2021 : The New Europe”, Wall Street Journal, November 19.

GUALINI E. (2001), “'New Programming' and the influence of transnational discourses in the reform of regional policy in Italy", European Planning Studies, 9, 6, pp. 755-771. 
HADJIMICHALIS C. (2011), "Uneven geographical development and socio-spatial justice and solidarity : European regions after the 2009 financial crisis", European Urban and Regional Studies, 18,3 , pp. 254-274.

HOLT-GIMÉNEZ E. \& PATEL R. (2009), Food Rebellions ! Crisis and the Hunger for Justice, Oxford, UK : Pambazuka Press.

LA REPUBBLICA (2010), Mutui. L'allarme di Bankitalia : "Il 5 \% non riesce a pagare”, 8 December.

HEATHERINGTON T. (2010), Wild Sardinia. Indigeneity and the Global Dreamtimes of Environmentalism, Seattle, WA, University of Washington Press.

MARTINELLI F. (2009), “Cassa per il Mezzogiorno”, in KITCHIN R. \& THRIFT N.J. (eds.), International Encyclopedia of Human Geography, Amsterdam, Elsevier, pp. 446-455.

MERRIFIELD A. (2011) “Crowd politics. Or, 'here comes everybuddy”, New Left Review, 71, pp. 103-114.

MOLÉ N. (2010), “Precarious subjects : Anticipating neoliberalism in Northern Italy'sworkplace”, American Anthropologist, 112, 1, pp. 38-53.

ONG A. (2007), "Neoliberalism as a mobile technology", Transactions of the Institute of British Geographers, 32, 1, pp. 3-8.

REINHART C. \& ROGOFF K. (2010), This Time is Different. Eight Centuries of Financial Folly, Princeton NJ, Princeton University Press.

ROSSI N. (2005), Mediterraneo del Nord. Un'altra idea del Mezzogiorno, Rome-Bari, Laterza.

ROSSI U. (2002) “Miti e realtà del nuovo sviluppo territoriale del Mezzogiorno : i termini e i problemi del dibattito", Archivio di Studi Urbani e Regionali, XXXIII, 73, pp. 77-99.

ROSSI U. (2004), "New Regionalism contested : some remarks in light of the case of the Mezzogiorno of Italy", International Journal of Urban and Regional Research, 28, 2, pp. 466-476.

ROSSI U. (2009) “Growth poles, growth centres”, in KITCHIN R. \& THRIFT N.J., (eds.), International Encyclopedia of Human Geography, Amsterdam, Elsevier, pp. 651-656.

ROSSI U. \& VANOLO A. (2012), Urban Political Geographies. A Global Perspective, London : Sage.

SHORT J.R., BREITBACH C., BUCKMAN S. \& ESSEX J. (2000), "From world cities to gateway cities : Extending the boundaries of globalisation theory", City, 4, 3, pp. 317-340.

VIESTI G. (2003), Abolire il Mezzogiorno, Rome-Bari, Laterza.

WILSON D. (2004), “Toward a contingent urban neoliberalism”, Urban Geography, 25, 8, pp. 771-783.

\section{NOTES}

1. This article is part of an ongoing research funded by the Leverhulme Trust (grant number F10/1010 A) under the title "Towards a postneoliberal urban deal" with colleagues Sara Gonzalez (principal investigator, University of Leeds), Martin Jones (Aberystwyth University), Stijn Oosterlynck (University of Antwerp) and Ramon Ribera Fumaz (Universitat Oberta de Catalunya). 2. In 2008 the Danish Maersk, a leading liner shipping in the container sector, decided to terminate the contract with Cagliari as its regional hub, being replaced by the German Hapag Lloyd about one year later. Transshipment ports, such as Cagliari, Taranto and Gioia Tauro in the Italian Mezzogiorno, are particularly exposed to the risks associated with the changing locational 
choices of global shipping companies operating under conditions of de facto monopoly. At the end of 2011 the port of Gioia Tauro - until then the busiest container port in Italy and second in the Mediterranean - has experienced vicissitudes similar to those described with reference to Cagliari.

3. In June 2011 about 12 interviews were conducted with qualified informants. These included: the President of the local branch of Confindustria (the Italian association of industrialists); the chairman of the local branch of CGIL, the left-leaning major trade union in Italy; the representative of the association of small retailers; an urban planner and an independent economic analyst acting as consultants for local government institutions ; two academics - one economist and one sociologist - specialising in economic development and labour market issues, respectively; the head of the committee supervising government expenditure within the regional government; a representative of a local bank; the director of Cagliari International Container Terminal ; the President of Cagliari Port Authority.

\section{ABSTRACTS}

Since 2010 Southern Europe has become the epicentre of the second phase of the global economic crisis that began two years earlier as a consequence of the bursting of the mortgage and financial bubble in the United States. In critical commentaries, this crisis has been understood as a crisis of neoliberalism as a mode of economic-political regulation. In the first part, this paper analyses the transition to a neoliberal mode of economic governance in Italy, understood in terms of "concerted neoliberalism", particularly looking at its implications for the North-South divide. In the second part, the paper looks at the effects of the global crisis in the Sardinia region, through the lens of the politics of resistance that has taken shape in this context. The paper concludes by reflecting on the limits to a regionalised politics of resistance, calling for an imaginative politics of renaissance at a cross-Southern European scale.

Depuis 2010 l'Europe méridionale est devenue l'épicentre de la seconde phase de la crise économique mondiale apparue deux ans plus tôt après l'éclatement de la bulle hypothécaire et financière aux Etats-Unis. Cette crise a été interprétée comme une crise du néolibéralisme en tant que mode de régulation économico-politique. Dans un premier temps, cet article analyse la transition vers un mode néolibéral de gouvernance économique en Italie, compris en termes de "néolibéralisme concerté", et plus particulièrement ses conséquences pour la division Nord-Sud. La seconde partie de l'article est consacrée aux effets de la crise mondiale en Sardaigne, vue à travers le prisme des stratégies de résistance mises en place dans ce contexte. L'article se conclut par une réflexion sur les limites d'une stratégie de résistance à l'échelle régionale, appelant à une politique de renaissance créative au niveau inter-méridional européen.

\section{INDEX}

Mots-clés: crise mondiale, néolibéralisme, Europe méridionale, Italie, Sardaigne, stratégies de résistance

Keywords: global crisis, neoliberalism, Southern Europe, Italy, Sardinia, politics of resistance 


\section{AUTHOR}

UGO ROSSI

University researcher in the Department of Economic-Social and Mathematical-Statistical Sciences, Economic Geography Discipline, Università di Torino, Italy, ugo.rossi@unito.it 